\title{
Use of solid residue from thermal power plant (fly ash) for enhancing sewage sludge anaerobic digestion: Influence of fly ash particle size.
}

\author{
S. Montalvo ${ }^{* a}$, I. Cahn ${ }^{\text {a }}$ R. Borja ${ }^{\text {b }}$ C. Huiliñir ${ }^{\mathrm{a}}$, L. Guerrero ${ }^{\mathrm{c}}$ \\ ${ }^{a}$ Universidad de Santiago de Chile, Av. Lib. Bdo. O`Higgins 3363, Santiago de Chile. Chile \\ ${ }^{b}$ Instituto de la Grasa, Campus Universitario Pablo de Olavide - Edificio 46, Ctra. de Utrera, Km. 1, \\ 41013 Sevilla, España. \\ ${ }^{c}$ Universidad Técnica Federico Santa María, Av. España 1680, Valparaíso, Chile
}

*Corresponding author at: Environmental Biotechnology Laboratory, Chemical Engineering Department, Universidad de Santiago de Chile, Av. Lib. Bdo. O'Higgins 3363, Santiago de Chile. Chile, Email address: silvio.montalvo@usach.cl

\section{Abstract}

The influence of fly ash particle size on methane production and anaerobic biodegradability was evaluated. Assays with different fly ash particle sizes (0.8 to 2.36 $\mathrm{mm})$ at a concentration of $50 \mathrm{mg} / \mathrm{L}$ were ran under mesophilic conditions. In anaerobic processes operating with fly ash, greater removal of both volatile total and suspended solids, chemical oxygen demand (total and soluble) was achieved, with an increase of methane production between $28 \%$ and $96 \%$ compared to the control reactors. The highest increase occurred at ash particles sizes of 1.0-1.4 mm. The metal concentrations in the digestates obtained after anaerobic digestion of sewage sludge are far below those considered as limiting for the use of sludge in soils.

Key words: anaerobic digestion; fly ash, metals; methane production; mixed sludge. 


\section{Introduction}

Nowadays one of the main problems related to the sanitary sector is the huge sewage sludge production in wastewater treatment plants. This waste must be treated before discarding it in the environment. As a frequently used method for the stabilization of waste activated sludge (WAS), anaerobic digestion (AD) had become the preferred method due to various advantages like lower energy consumption, less carbon content but smaller total volume of the digested sludge, and higher methane production (Young et al., 2013). However, due to the amount of organic matter in suspension that these sludge contains and the low metabolism of methanogenic microorganisms, high hydraulic retention times are required to carry out a successful development of the anaerobic process (Zhen et al., 2017).

The microorganisms that produce methane in anaerobic digestion are the methanogenic archaea, in such a way that the stimulation of its growth and metabolism improves the anaerobic process and methane production. It is well known that methanogenic archaea have nutritional requirements of specific metals such as iron, nickel, cobalt, copper, and molybdenum (Qiang et al., 2013). Other micronutrients such as cadmium, manganese, zinc, and copper are also accounted for in the digestion process (Schattauer et al., 2011). Lack of sufficient nutrients and trace elements can severely limit the growth of microorganisms and consequently the efficiency of the process (Park et al., 2010). Several studies have shown the need of trace elements in the anaerobic digestion of both solid and liquid wastes (Choong et al., 2016). The anaerobic digestion of solid wastes is much slower because in this case the hydrolysis stage is more difficult 
to carry out and for that reason it is necessary to provide the best conditions for the development of the anaerobiosis, such as the presence of stimulating metals (Wall et al., 2014).

Although the importance of metals is clear, their application to anaerobic processes is limited mainly by the high cost of trace salts used for this purpose. In this context, the use of a cheaper source of trace elements could help to control this process without additional expenses. In the combustion processes in thermal power plants, a large amount of fly-ash products (FAP) is generated. FAP from power plants is taken to landfills or stored in ash lagoons (Haynes, 2009). These disposal strategies not only increase the burden on landfills, but they also have significant impact on the surrounding habitats and ecosystems (Lou and Nair, 2009). The disposal of FAP is problematic in traditional landfills, but they can be recycled into useful materials for various environmental applications mainly as adsorbents of contaminating compounds (Kwong and Chao, 2010). In this research a solid residue called fly ash, produced in thermal power plants that use bituminous coal as fuel, is applied to sludge anaerobic digestion. The use of this kind of residue as a source of trace elements for anaerobic digestion has been scarcely reported in the literature. Lo (2005), in laboratory scale anaerobic reactors to simulate the landfill site operation, studied the effect of refuse and incinerator bottom ash on anaerobic digestion. He showed that the range of heavy metal concentrations showed neither significant stimulatory nor inhibitory effects on anaerobic digesters, but the released alkali metals seemed to exert a beneficial effect on the anaerobic digesters, improving the acid's neutralizing capacity. Lo et al. (2009) showed that the use of 
municipal solid waste incinerator (MSWI) fly ash in anaerobic digestion enhanced the gas production rate, while heavy metals exerted no inhibitory effect on MSW digestion in all reactors. They concluded that enhanced gas production rate by methanogenic activity in the fly ash-added bioreactors was potentially stimulated by optimal alkali and trace metal concentrations with near-neutral $\mathrm{pH}$. These phenomena indicated that proper amounts of MSWI fly ash co-disposed or co-digested with MSW, could facilitate bacterial activity, digestion efficiency, and gas production rate. There is only one very recent report about application of fly ash from thermal power plant to sewage sludge anaerobic digestion (Huiliñir et al., 2017). There are no reports in the literature describing the effect of the particle size of these ashes on anaerobic digestion processes. However, particle size plays an important role in physical, chemical, and biological processes affecting hydrodynamics and mass transfer characteristics, available specific surfaces, substrate compositions, etc. (Montalvo et al., 2005).

Taking this background into consideration, the aim of the present research was to evaluate the influence of fly ash particle size on the anaerobic digestion process of sewage sludge. The metal concentrations in the digestate were also studied in order to know if this application can decrease metal concentration in the digestate in an important way.

\section{Material and Methods}

The influence of fly ash particle size on the process was studied, carrying out three experimental runs. Each run was performed with a specific sludge sample (a sample of sludge taken in a random manner) guarantees that the results obtained are representative. 
On the other hand, each experimental run, corresponding to a specific anaerobic process (a process working with a particular particle size), was performed in duplicate.

\subsection{Raw materials}

\subsubsection{Mixed sludge used}

The substrate used for all the assays was a mixture of primary sludge (60\%) and secondary sludge (waste activated sludge) (40\%). This mixture is called mixed sludge, and it was coming from "La Farfana”, a municipal wastewater treatment plant operated by “Aguas Andinas” located in Santiago, Chile. The main characteristics of the mixed sludge samples used in the experiments were: $\mathrm{pH}$ 5.3-5,4; volatile total solids (VTS), 19500 - 24000 mg.L ${ }^{-1}$; volatile suspended solid (VSS), 15000-17300 mg.L ${ }^{-1}$; total Kjeldahl nitrogen (TKN), 1301-1251 mg L ${ }^{-1}$; total ammonia nitrogen (TAN), 400- 430 mg. $\mathrm{L}^{-1}$. The sulfur concentration in all the mixed sludge samples was negligible.

\subsubsection{Anaerobic inoculum}

The anaerobic inoculum was obtained from a sludge anaerobic reactor operated in “La Farfana”. It had a specific methanogenic activity of $0.32 \mathrm{~g}\left(\mathrm{CH}_{4}-\mathrm{COD}\right) \cdot \mathrm{g}^{-1}$ VSS $\cdot$ day $^{-1}$; VSS of 90-115 mg $\cdot \mathrm{L}^{-1}$; dissolved $\mathrm{H}_{2} \mathrm{~S} 12-15 \mathrm{mg} \cdot \mathrm{L}^{-1}$; and a $\mathrm{pH}$ of 7.4.

\subsubsection{Characteristics of the fly ash used}

The fly ash was obtained from a thermoelectric power plant located in the north of Chile. Ash was taken from electrostatic precipitators used to collect particulate matter generated by the combustion of bituminous coal, which is placed before the gaseous effluents that leave the plant. Table 1 shows the main chemical characteristics of this fly ash, whose $\mathrm{pH}$ was $11.07 \pm 0.7$. 
The ash-size distribution used in the experiments was produced on a screening equipment, where three ranges of particle sizes were selected: $<0.8 \mathrm{~mm}$ (Size 1); 1-1.4 mm (Size 2); and 2 - 2.36 mm (Size 3).

\subsection{Experimental design and set up}

The anaerobic reactors used were glass mini-reactors of $250 \mathrm{~mL}$ total volume and $200 \mathrm{~mL}$ effective volume. Each reactor was filled with $40 \mathrm{~mL}$ of inoculum and $160 \mathrm{~mL}$ of mixed sludge, which correspond to $20 \%$ and $80 \%$ of the effective volume (Montalvo et al, 2016), respectively. All the reactors were sealed and the headspace of each flask was flushed with nitrogen at the beginning of the assay. The produced biogas was passed through $3 \% \mathrm{NaOH}$ solution to capture $\mathrm{CO}_{2}$, and the remaining gas was assumed to be methane. This system for measuring methane production is commonly used in these kinds of experiments (Yang et al., 2016). Due to the importance of keeping the homogeneity of the sludge within the reactors, they were subjected to a moderate manual stirring several times per day during some seconds. The anaerobic digester temperature was kept at $35 \pm 2{ }^{\circ} \mathrm{C}$ using automatically controlled aquarium heaters. The reactors operated in batch mode for 30 days, at which time methane accumulation remained constant. Methane production was monitored daily throughout the process.

Experimental runs were carried out by adding $50 \mathrm{mg} \cdot \mathrm{L}^{-1}$ of fly ash to the reactors according to the results obtained by Huiliñir et al. (2017). The experiments were carried out according to the experimental methodology presented in Figure 1. Three experimental runs, AII-1, AII-2, and AII-3 (with three sludge samples taken on different days) were carried out in these experiments working with three ash particle sizes: $<0.8$ 
$\mathrm{mm} ; 1$-1.4 mm and 2-2.36 mm. Each run was performed in duplicate with 56 discontinuous digesters, with three ash sizes, except for 2 reactors that were used as controls (without addition of ash). The reactors labeled with ${ }^{\circ}$ are the replicates or duplicates. It is seen that each alternative evaluated begins with 8 reactors and their duplicates, and from time to time [2 (T1.1 $\left.{ }^{\circ}\right), 5\left(\mathrm{~T} 1.2^{\circ}\right), 9\left(\mathrm{~T} 1.3^{\circ}\right), 12\left(\mathrm{~T} 1.4^{\circ}\right), 16\left(\mathrm{~T} 1.5^{\circ}\right)$, $19\left(\mathrm{~T} 1.6^{\circ}\right), 23\left(\mathrm{~T} 1.7^{\circ}\right), 26\left(\mathrm{~T} 1.8^{\circ}\right)$, and 30(T1.9 $)$ days] a couple of reactors were taken from the system, performing the corresponding analyses that will be representative results for that day of digestion. In this way each value of the analyzed samples represent a point of the evolution curves corresponding to the different physicochemical parameters evaluated. A total of 54 mini digesters were used, 48 of them to analyze the effect of ash size on the digestion of the sludge and its characteristics. The remaining 6 reactors (Figure 1, represented by 1.9, 2.9, and 3.9) were used exclusively to measure the effect of ash addition (particle size) on the daily methane generation from the sludge.

\subsection{Chemical and statistical analyses}

The following chemical parameters were determined: total chemical oxygen demand $\left(\mathrm{COD}_{\mathrm{t}}\right)$, soluble chemical oxygen demand $\left(\mathrm{COD}_{\mathrm{s}}\right)$, total volatile solids (TVS), volatile suspended solids (VSS), alkalinity, sulfate, sulfide, $\mathrm{pH}$, total Kjeldahl nitrogen (TKN), and ammonia. These parameters were analyzed according to APHA Standard Methods (APHA et al., 2012). All analytical determinations were made at least in duplicate with a frequency of two or three times per week, except methane volume, 
which was measured daily. The determination of metal concentrations was performed using a Perkin Elmer Optima 3000 ICP according to standard protocols based on official methods of the US-EPA (Cortés and Montalvo, 2016).

The Minitab 8 software was used for the statistical processing and analysis of the data. A Fisher distribution (Test F) analysis was performed and a comparison of 95\% confidence intervals for mean values was made for all cases studied.

\section{Results and Discussion}

Different runs were made with the purpose of observing to what extent the variations in the characteristics of the mixed sludge affected the behavior of the digesters. The results of biodegradation and methane production showed variations of the order of only 3 - 5\%, so the figures of only one experimental run will be shown, although in the corresponding tables the main results of all the experimental runs are shown.

Figure 2 shows initial and final alkalinity in digesters, and it is seen that those values are very high from the beginning. Fly ash $\mathrm{pH}$ has an important contribution to those values, taking account that it contains a suitable liming material derived primarily form $\mathrm{CaO}, \mathrm{MgO}$ and other alkaline metal oxides that react with water to generate net alkalinity. On the other hand, as the degradation of the nitrogen-containing organic matter takes place, ammoniacal nitrogen is formed, which contributes to the elevation of the alkalinity and the $\mathrm{pH}$ of the medium. The ammonium contained inside organic compounds is about $900 \mathrm{mg} . \mathrm{L}^{-1}$ according to the initial value of TKN and ammonia present in mixed sludge. However, no inhibition process was seen due to these 
alkalinities, considering optimum values of $2000-4000 \mathrm{mg} \mathrm{CaCO}_{3} \mathrm{~L}^{-1}$ ( $\mathrm{Li}$ et al., 2013). Martín-González et al. (2013) operated an anaerobic digester with source-sorted organic fraction of municipal wastes working with high alkalinity of 8 g. $\mathrm{L}^{-1}$ as $\mathrm{CaCO}_{3}$ observing a good behavior of the process. The $\mathrm{pH}$ increased continuously over time, reaching values around 7.6. This behavior may be due to the fact that the high initial amount of organic matter could generate a significant amount of volatile fatty acids that can interact with the high alkalinity present in the digesters. The increased alkalinity in the digesters is mainly due to the total ammonia generation from the hydrolysis process that takes place in the initial stage of the anaerobiosis, releasing the ammonium which is found to be part of the proteins present in the sludge (Li et al., 2017).

Total Ammonia Nitrogen $\left(\mathrm{NH}_{3}+\mathrm{NH}_{4}{ }^{+}\right.$, TAN) increased through the anaerobic processes, achieving values at 30 days of $974,1081,1115$, and $900 \mathrm{mg} \cdot \mathrm{L}^{-1}$ for the controls, and $<08,1-1.4$, and 2-2.36 fly ash particle reactors. This increase is due to the fact that during the hydrolysis and fermentation stage of the anaerobic process of nitrogenous compounds such as proteins and amino acids the ammoniacal compounds are released into the liquid medium. In any case these values were always lower than those considered inhibitory or toxic for anaerobic processes $\left(>1500 \mathrm{mg} \cdot \mathrm{L}^{-1}\right)($ Chen et al., 2008). Another factor that contributes to $\mathrm{pH}$ increase is the $\mathrm{CO}_{2}$ consumption by the hydrogenophylic methanogenic archaea present in the inoculum, as well as by the acidogenic bacteria (Amani et al., 2010). Finally, the sulfur concentration in the digesters was between 30 and $70 \mathrm{mg} \cdot \mathrm{L}^{-1}$, values lower than those considered inhibitory in anaerobic digestion processes by most authors (Guerrero et al., 2015). 
Figures 3 and 4 show the evolution of VTS and VSS with time for the different anaerobic digesters operating under the same conditions (average value of each two reactors) in the experimental series II: AII-1. As can be seen, The VTS and VSS contents decrease with time in all cases, with the removal of organic matter higher for the medium-sized particles (1-1.4 mm). Through the Fisher distribution (Test F) it was possible to confirm that the effect of the different conditions on methane production was statistically different, with 95\% confidence.

Figure 5 illustrates the variation of the accumulated methane production with time, showing that methane production started virtually at the beginning of the process, which may be due to the characteristics of the mixed sludge subjected to anaerobic digestion and the inoculum that was used. Figure 5 also shows that maximum methane production was achieved with the medium-sized particles (1-1.4 mm), in agreement with the results obtained for higher VTS and VSS removal (Figure 2). It is also seen that the lowest methane production was reached for the control reactor.

The four experimental conditions represented in Figure 5 show how the substrate is being consumed by the microorganisms, generating methane, with an important increase of the methane production rate around days 16 - 17, significantly decreasing methane production from day 25.

From the behavior shown in Figure 5, it can be estimated that the increase in the methane yield (accumulated methane production per initial volatile suspended solid) for the different reactors, containing particle sizes T1 $(<0.8 \mathrm{~mm})$, T2 (1-1.4 mm) and T3 (2- 
$2.36 \mathrm{~mm}$ ), with respect to the control reactor were $59 \%, 96 \%$ and $23 \%$, respectively (Figure 5a), and 47\%, 85\% and 30\%, respectively (Figure 5b). Through the Fisher distribution (Test F) it was confirmed that the effect of the various conditions on methane production was statistically different with 95\% confidence.

Table 2 shows a summary of the results achieved in the three experimental runs. The removal efficiency in percentage $(\% R)$ of the different parameters $(P)$ were calculated according to the following equation:

$$
\% R=\left[\frac{(\text { Initial value of } P-\text { Final value of } P)}{\text { Initial value of } P}\right] \times 100
$$

where $P$ could be: VTS, VSS, $\mathrm{COD}_{\mathrm{t}}$ and $\mathrm{COD}_{\mathrm{s}}$

Removal of all parameters analyzed (VTS, VSS, $\mathrm{COD}_{t}$ and $\mathrm{COD}_{\mathrm{s}}$ ) for the different particle sizes tested were always higher than those obtained for the control rector. This fact shows that the addition of fly ash did not cause any toxicity or inhibition to the system.

Smaller particle sizes $(<0.8 \mathrm{~mm})$ favor the contact of microorganisms - fly ash as well as the solution of the solid waste (ash). However, intermediate particle sizes (1-1.4 $\mathrm{mm}$ ) favor an additional enhancement, probably because there is an attachment of microorganisms to the surface of the particles that is more favorable for somewhat larger particle sizes (Montalvo et al., 2005). This can be explained because several studies made by Scanning Electron Microscopy (SEM) reveal that the surface of fly ash is usually irregular, and it appears to be porous in a potential state of fragmentation with 
small and rough particles (Duang et al., 2017). Additionally, another component in the fly ash, unburned carbon, is a black irregular porous particle (Kiani et al., 2017). For particle sizes greater than 1-1.4 mm, the above-mentioned advantages disappear, causing a decrease in the removal efficiency. Therefore, particle sizes of 1-1.4 mm can be considered as optimal.

The results obtained show that the addition of fly ash stimulates methane production, probably largely due to the contribution of some metals essential for the good growth and metabolism of methanogenic archaea (Thanh et al., 2016). It is well known that the quantitative influence, positive or negative, of the metals on the anaerobic process depends on diverse factors such as temperature, the way in which the metals are added, metal concentration, possible synergic effects among various metals, etc. (Zhang et al., 2015). Table 5 shows the stimulant metal concentrations proposed by several authors for anaerobic digestion processes.

According to the dosage of fly ash applied $\left(50 \mathrm{mg} \cdot \mathrm{L}^{-1}\right)$, and the elements present in the ash, the metal concentrations with possible stimulant effect present in the digesters can be calculated according to the following equation:

$$
M=50 \times 10^{-6} / M(F A)
$$

Where $M$ is the individual metal ( $\mathrm{Cu}, \mathrm{Ni}, \mathrm{Fe}, \mathrm{Mn}, \mathrm{B})$ concentration in the digester in mg. $\mathrm{L}^{-1}$ and $M(F A)$ is the amount of individual metal (g) in $1 \mathrm{~kg}$ of fly ash (Table 1). Therefore, according to equation (2) the $M$ values were: $\mathrm{Cu}, 0.00011 \mathrm{mg} \cdot \mathrm{L}^{-1}$; $\mathrm{Ni}, 0.0003$ $\mathrm{mg} \cdot \mathrm{L}^{-1}$; Fe, $0.154 \mathrm{mg} \cdot \mathrm{L}^{-1} ; \mathrm{Mn}, 0.0011 \mathrm{mg} \cdot \mathrm{L}^{-1}$, and $\mathrm{B}, 0.018 \mathrm{mg} \cdot \mathrm{L}^{-1}$. Comparing these values with those included in Table 3, it can be concluded that the concentrations present 
in the experimental digesters are well below those considered as stimulants for the anaerobic process, considering that all of them were bioavailable, which is the best scenario, because sometimes only because of solubility the microorganisms cannot gain access to these amounts of metals. It should also be noted that the fly ashes are generated by a process of oxidation at high temperature (oxidation) so the metals that are originally in the fuel are mainly converted to oxides that are poorly soluble compounds. A particular influence of these oxides on the anaerobic process is also not expected due to their distribution on the surface of fly ash as they are more or less evenly distributed over fly ash (Pandey et al., 2017; Weibel et al., 2017).

From the data shown in Table 3, it can be argued that the most influential metal on the improvement in methane production is, in this case, iron. Iron has become one of the most prominent additives to improve anaerobic digestion performance owing to its conductive properties and low price. Reported iron advantages also include: its capacity to decrease oxidative-reductive potential (ORP) of the anaerobic digestion media and therefore provide a more favorable environment for anaerobic digestion; and its role as a cofactor of several key enzymatic activities, such as pyruvate-ferrodoxin oxidoreductase, which contains Fe-S clusters and plays a key role in fermentation (Romero-Güiza, 2016). The mechanism for accelerating and improving methane generation may be associated with the effect of trace elements on different types of enzymes, especially the metalloenzymes. According to the literature (Choong et al., 2016), the trace elements in the metalloenzyme are functioning to form the active site, the cofactor, and the structure itself. The importance of iron in the anaerobic process is also reflected in that the general 
trace element requirement trend for metalloenzymes in methanogenesis can be simplified as $\mathrm{Fe}>>\mathrm{Ni}>\mathrm{Co}>\mathrm{Zn}=\mathrm{Mo} / \mathrm{W}$ (Choong et al., 2016). For all these reasons, there are a significant number of articles reporting a significant increase in methane production in anaerobic processes by adding iron compounds at different concentrations in digesters operating with various wastes (Wang et al., 2017). In this sense, Hao et al. (2017) added an industrial residual, waste iron scraps (WISs) in a two-phase process: acidogenic phase and methanogenic phase and through detection on both FISH and enzymatic activities of involved microorganisms revealed that the stimulating effects of WISs on anaerobes (both catabolism and anabolism) could play an important (96.3\%) role in enhancing $\mathrm{CH}_{4}$ production, which would facilitate hydrolysis of refractory organics and improvement of electron transport rate. The results of these authors demonstrate that the positive influence of iron on the anaerobic process is manifested mainly in the stage of methanogenesis ratifying what the great majority of authors have planted on the effect of the metals on the anaerobic process. Exceptionally the $\mathrm{Fe}^{\mathrm{o}}$ (also named as zero valent iron (ZVI)) has been found able to accelerate the hydrolysis and fermentation stages due to its action as electron donor (Karri et al., 2005). However, consideration should be given not only to the individual values taken as stimulants, but also to the positive synergy that can be exerted by all these elements, including $\mathrm{Cu}$ and $\mathrm{Ni}$, which are in very small amounts (Choong et al., 2016).

As was previously mentioned, it is a proven fact that metals have a positive influence at certain concentrations, so the future perspectives of the fly ash on methane production and biodegradability in anaerobic processes will be determined by two main 
factors: application of the optimum doses according to the residue or substrate and the way of addition of the fly ash according to the anaerobic process or reactor used.

In spite of the positive results obtained when providing fly ash to the anaerobic digestion of sludge, the application of this procedure could be limited if the concentration of metals in the digested sludge (digestate) exceeds the maximum values allowed to use this sludge as soil and/or fertilizer conditioners. Chilean legislation (Ministerio Secretaría General de la Presidencia, 2009), in article 24 of Supreme Decree No. 4 (Decreto Supremo $N^{\circ}$ 4, 2009) for the management of sludge from urban wastewater treatment plants (UWTPs), establishes maximum concentrations of metals in sludge to be applied to agricultural soils (class A) and degraded soils (class B). The comparative results between the characteristics of the digested sludge obtained for the different particle sizes and the values considered to belong to class A and/or B sludge are shown in Table 4.

As shown in Table 4, none of the conditions studied in the present work exceeds the limits established by Chilean legislation, allowing the use of fly ash as a source of trace metals in the anaerobic digestion process of mixed sludge.

\section{Conclusions}

The influence of fly ash particle sizes from 0.8 to $2.36 \mathrm{~mm}$ on methane production and anaerobic biodegradability were evaluated. It was found that the addition of fly ash from thermoelectric plants used as of metal trace element supplements stimulates the degradation of organic matter and the generation of methane in anaerobic digestion of 
mixed sludge, with the process with fly ash particle sizes of 1-1.4 mm the one that achieved the highest degradation of organic matter and highest methane production. Digested sludge obtained with fly ash application presents metal concentrations well below those required for use in agricultural soils.

\section{Acknowledgment}

The authors acknowledge the financial support provided by FONDECYT (Chile) under Project 1030315.

\section{References}

1. APHA, AWWA, WPCF, 2012. Standard Methods for the Examination of Water and Wastewater $22^{\text {nd }}$ ed. AWWA, Washington, D.C.

2. Amani, T., Nosrati, M., Sreekrishnan, T.R., 2010. Anaerobic digestion from the viewpoint of microbiological, chemical, and operational aspects — a review. Environmental Reviews 18, 255-278.

3. Chen, Y., Cheng, J. J., and Creamer, K. S., 2008. Inhibition of anaerobic digestion process: A review. Bioresource Technology 99, 4044-4064.

4. Choong, Y.Y., Norli, I., Abdullah, A.Z., Yhaya, M.F., 2016. Impacts of trace element supplementation on the performance of anaerobic digestion process: A critical review. Bioresource Technology 209, 369-379.

5. Córdoba, V., Colavolpe, M.B., Fernández, M., Santalla, E., Albertó, E., 2016. Potential methane production of spent sawdust used in the cultivation of Gymnopilus pampeanus. Journal of Environmental Chemical Engineering 4, 4418-4425. 
6. Cortés, I., Montalvo, S., 2016. Evaluation of potential methane generation in the investigation of an abandoned contaminated landfill in Santiago, Chile. Brazilian Journal of Chemical Engineering, 33, 723-731.

7. Dong, B., Liu, X., Dai, L., Dai, X., 2013. Changes of heavy metal speciation during high-solid anaerobic digestion of sewage sludge. Bioresource Technology, 131, 152158.

8. Duang, P., Tan Ch., Zhiu, W., 2017. Comprehensive strength and microstructure of fly ash based geopolymer blended with silica fume under thermal cycle. Cement and Concrete Composites, 78, 108-119.

9. Facchin, V., Cavinato, C., Fatone, F., Pavan, P., Cecchi, F., Bolzonella, D., 2013. Effect of trace element supplementation on the mesophilic anaerobic digestion of food waste in batch trials: The influence of inoculum origin. Biochemical Engineering Journal, 70, 71-77.

10. Guerrero, L., Montalvo, S., Huiliñir, C., Campos, J., Barahona, A., Borja, R., 2015. Advances in the biological removal of sulphides from aqueous phase in anaerobic processes: A review. Environmental Reviews 24, 84-100.

11. Hao, X., Wei, J., van Loosdrecht, M.C.M., Cao, D., 2017. Analysing the mechanisms of sludge digestion enhanced by iron. Water Research, 117, 58-67. 12. Haynes, R.J., 2009. Reclamation and revegetation of fly ash disposal sites challenges and research needs. Journal of Environmental Management 90, 43-53. 
13. Huiliñir, C., Montalvo, S., Guerrero, L., 2015. Biodegradability and methane production from secondary paper and pulp sludge: Effect of fly ash and modeling. Water Science and Technology 72, $230-237$.

14. Huiliñir, C., Pinto-Villegas, P., Castillo, A., Montalvo, S., Guerrero, L., 2017.

Biochemical methane potential from sewage sludge: Effect of an aerobic pretreatment and fly ash addition as source of trace elements. Waste Management, in press 15. Karri, S., Sierra-Álvarez, R., Field, J.A., 2005. Zero valent iron as an electron-donor for methanogenesis and sulfate reduction in anaerobic sludge. Biotechnology Bioengineering, 92, 810-819.

16. Kiani, A., Zhou, J., Galvin, K.P., 2017. Detailed characterisation and separation of fly ash fed to the Inverted Reflux Classifier. Fuel Processing Technology 155, 114-123. 17. Kim, M., Gomec, C.Y., Ahn, Y., Speece, R.E., 2003. Hydrolysis and acidogenesis of particulate organic material in mesophilic and thermophilic anaerobic digestion. Environonmental Technology, 24, 1183-1190.

18. Kloss, R., 1986. Planung von Biogasanlagen nach technischwirtschaftlichen Kriterien. München, Wien: R. Oldenbourg Verlag. 19. Kwong, C.W., Chao, C.Y.H., 2010. Fly-ash products from biomass co-combustion for VOC control. Bioresource Technology 101, 1075-1081.

20. Li, Y., Zhang, R., Chen, Ch., Liu, G., He, Y., Liu, X., 2013. Biogas production from co-digestion of corn stover and chicken manure under anaerobic wet, hemi-solid, and solid state conditions. Bioresource Technology 149, 406-412. 
21. Li, X., Peng, Y., He, Y., Wang, Sh., Guo, S., Li, L., 2017. Anaerobic stabilization of waste activated sludge at different temperatures and solid retention times: Evaluation by sludge reduction, soluble chemical oxygen demand release and dehydration capability. Bioresource Technology 227, 398-403.

22. Liu, Ch., Li, H., Zhang, Y., Liu, C., 2016. Improve biogas production from loworganic-content sludge through high-solids anaerobic co-digestion with food waste. Bioresource Technology 219, 252-260.

23. Lo, H. M., 2005. Metals behaviors of MSWI bottom ash co-digested anaerobically with MSW. Resources, Conservation and Recycling 43, 263-280.

24. Lo, H.M., Liu, M.H., Pai, T.Y., Liu, W.F., Lin, C.Y., Wang, S.C., Banks, C.J., Hung, C.H., Chiang, C.F., Lin, K.C., Chen, P.H., Chen, J.K., Chiu, H.Y., Su, M.H., Kurniawan, T.A., Wu, K.C., Hsieh, C.Y., Hsu, H.S., 2009. Biostabilization assessment of MSW codisposed with MSWI fly ash in anaerobic bioreactors. Journal of Hazardous Materials $162,1233-1242$.

25. Lou, X.F., Nair, J., 2009. The impact of landfilling and composting on greenhouse gas emissions - a review. Bioresource Technology 100, 3792-3798.

26. Martín, M.A., De la Rubia M.A., Martín, A., Borja, R., Montalvo, S., Sánchez, E., 2010. Kinetic evaluation of the psychrophilic anaerobic digestion of synthetic domestic sewage using an upflow filter. Bioresource Technology 101, 131-137.

27. Martín-González, L., Font, X., Vicent, T. 2013. Alkalinity ratios to identify process imbalances in anaerobic digesters treating source-sorted organic fraction of municipal wastes. Biochemical Engineering Journal 76, 1-5. 
28. MINISTERIO SECRETARÍA GENERAL DE LA PRESIDENCIA, República de Chile, 2009. Decreto Supremo \#4 para el manejo de lodos generados en plantas de tratamiento de aguas servidas.

29. Montalvo, S., Díaz, F., Guerrero, L., Sánchez, E., Borja, R., 2005. Effect of particle size and doses of zeolite addition on anaerobic digestion processes of synthetic and piggery wastes. Process Biochemistry 40, 1475-1481.

30. Montalvo, S., Huiliñir, C, Ojeda, F., Castillo, A., Guerrero, L. 2016. Microaerobic pretreatment of sewage sludge: Effect of air flow rate, pretreatment time and temperature on the aerobic process and methane generation. International Bioderioration \& Biodegradation 110, 1-7.

31. Mudrack, K., Kunst, S., 2003. Biologie der Abwasserreinigung (5th ed.). Heidelberg, Berlin: Spektrum Akademischer Verlag.

32. Pandey, Sh.K., Bhattacharya, T., 2017. Mobility, Ecological risk and change in surface morphology during sequential chemical extraction of heavy metals in fly ash: A case study. Environmental Technology \& Innovation, in press.

33. Park, C., Bega, A., Unlu, C., Chadderton, R. A., McKean, W. R., Kohl, P. M., Hunt, J. A., Keaney, J., Willis, J. L., Duran, M., 2010. Acetoclastic methanogens in an anaerobic digester could be susceptible to trace metal supplementation. Water Science and Technology 62, 2905-2911.

34. Pobeheim, H., Munk, B., Johansson, J., Guebitz, G. M., 2010. Influence of trace elements on methane formation from a synthetic model substrate for maize silage. Bioresource Technology 101, 836-839. 
35. Qiang, H., Niu, O., Chi, Y., Li, Y., 2013. Trace metals requirements for continuous thermophilic methane fermentation of high-solid food waste. Chemical Engineering Journal, 222, 330-336.

36. Romero-Güiza, M.S., Vila, J., Mata-Álvarez, J., Chimenos, J.M., Astals, S., 2016. The role of additives on anaerobic digestion: A review. Renewable and Sustainable Energy Reviews, 58, 1486-1499.

37. Sahm, H., 1981. Biologie der Methan-Bildung (Biology of Methane Formation). Chemie Ingenieur Technik 53, 854-863.

38. Schattauer, A., Abdoun, E., Weiland, P., Plöchl, M., Heiermann, M., 2011. Abundance of trace elements in demonstration biogas plants. Biosystem Engineering, 108, 57-65.

39. Seyfried, C.F., Bode, H., Austermann-Haun, U., Brunner, G., von Hagel, G., Kroiss, H., 1990. Anaerobe Verfahren zur Behandlung von Industrieabwa“ ssern. Korrespondenz Abwasser 37, 1247-1251.

40. Thanh, P.M., Ketheesan, B., Yan, Z., Stuckey, D., 2016. Trace metal speciation and bioavailability in anaerobic digestion: A review. Biotechnology Advances 34, 122-136. 41. Wall, D.M., Allen, E., Straccialini, B., O’Kiely, P., Murphy, J.D., 2014. The effect of trace element addition to mono-digestion of grass silage at high organic loading rates. Bioresource Technology, 172, 349-355.

42. Wang, Y., Ren, G., Zhang, T., Zou, Sh., Wang, X., 2017. Effect of magnetite powder on anaerobic co-digestion of pig manure and wheat Straw. Waste Management, 66, 4652. 
43. Weibel, G., Eggenberger, U., Schlumberger, S., Mäder, U.K., 2017. Chemical associations and mobilization of heavy metals in fly ash from municipal solid waste incineration. Waste Management, 62, 147-159.

44. Weiland, P., 2006. Anforderungen an Pflanzen seitens des Biogasanlagenbetreibers. In12. Thüringer Bioenergietag; Schriftenreihe der TLL, 12, 26-32.

45. Yang, H., Deng, L., Liu, G., Yang, D., Liu, Y., Chen, Z., 2016. A model for methane production in anaerobic digestion of swine wastewater. Water Research 102, 464-474. 46. Young, M.N., Marcus, A.K., Rittmann, B.E., 2013. A Combined Activated Sludge Anaerobic Digestion Model (CASADM) to understand the role of anaerobic sludge recycling in wastewater treatment plant performance. Bioresource Technology, 136, 196-204.

47. Zhang, L., Lee, Y-W., Jahng, D., 2011. Anaerobic co-digestion of food waste and piggery wastewater: Focusing on the role trace elements. Bioresource Technology, 102, 5048-5059.

48. Zhang, W., Zhang, L., Li, A., 2015. Enhanced anaerobic digestion of food waste by trace metal elements supplementation and reduced metals dosage by Green chelating agent [S,S]-EDDS via improving metals bioavailability. Water Research 84, 266-277. 
Table 1. Chemical characterization of the fly ash from a thermal power plant used in the experiments.

\begin{tabular}{|c|c|}
\hline & Fly ash \\
\hline Element & Values $\left(\mathrm{mg} \cdot \mathrm{kg}^{-1}\right)$ \\
\hline Cd & $<\mathrm{DL}$ \\
\hline Zn & 5.40 \\
\hline $\mathrm{Cr}$ & 2.92 \\
\hline As & $<\mathrm{DL}$ \\
\hline $\mathbf{C u}$ & 2.21 \\
\hline $\mathbf{N i}$ & 6.17 \\
\hline $\mathbf{P b}$ & $<\mathrm{DL}$ \\
\hline Al & 1315.42 \\
\hline Se & $<\mathrm{DL}$ \\
\hline Mn & 21.05 \\
\hline $\mathbf{V}$ & 13.36 \\
\hline Ba & 44.36 \\
\hline Co & $<\mathrm{DL}$ \\
\hline Mo & $<\mathrm{DL}$ \\
\hline Be & $<\mathrm{DL}$ \\
\hline $\mathbf{B}$ & 35.03 \\
\hline $\mathbf{F e}$ & 3083.58 \\
\hline
\end{tabular}

DL: Detection Limit 
Table 2. Organization of the digesters during the three experimental runs of the Series II.

Fly ash

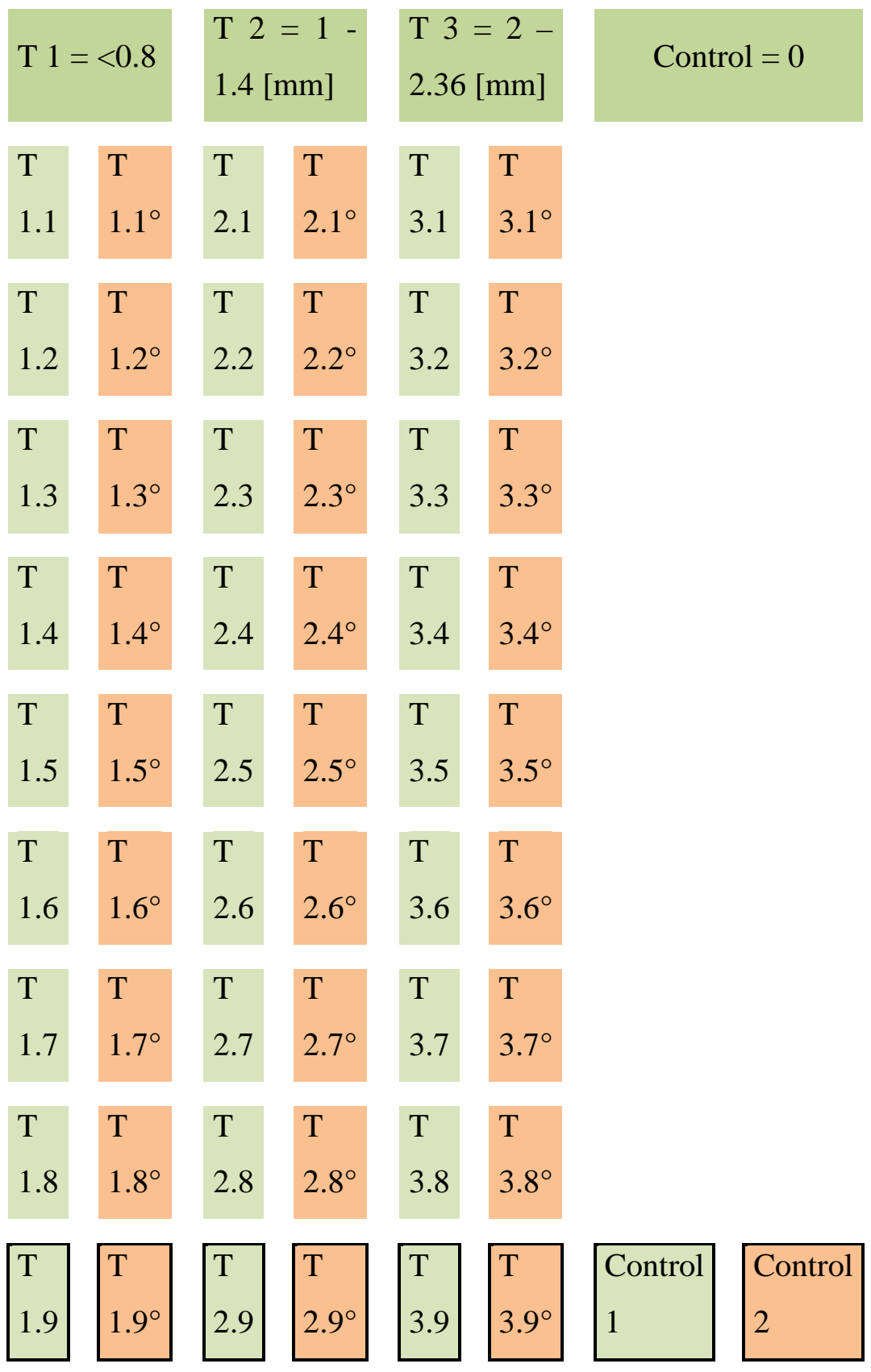


Table 3. Summary of the results achieved in the experimental Series .

\begin{tabular}{|c|c|c|c|c|}
\hline Parameter & Fly ash particle size & AII-1 & AII-2 & AII-3 \\
\hline \multirow{4}{*}{ VTS Removal [\%] } & Control & 33.00 & 31.20 & 32.57 \\
\hline & $<0.8 \mathrm{~mm}$ & 36.40 & 32.59 & 33.89 \\
\hline & $1-1.4 \mathrm{~mm}$ & 39.00 & 34.72 & 40.11 \\
\hline & $2-2.36 \mathrm{~mm}$ & 35.84 & 28.11 & 31.65 \\
\hline \multirow{4}{*}{ VSS Removal [\%] } & Control & 15.00 & 27.49 & 29.00 \\
\hline & $<0.8 \mathrm{~mm}$ & 28.90 & 30.11 & 32.73 \\
\hline & $1-1.4 \mathrm{~mm}$ & 35 & 34.72 & 37.00 \\
\hline & $2-2.36 \mathrm{~mm}$ & 27.27 & 24.73 & 31.12 \\
\hline \multirow{4}{*}{ CODt Removal [\%] } & Control & 30.00 & 34.94 & 33.56 \\
\hline & $<0.8 \mathrm{~mm}$ & 44.51 & 46.97 & 45.38 \\
\hline & $1-1.4 \mathrm{~mm}$ & 46.27 & 54.29 & 57.02 \\
\hline & $2-2.36 \mathrm{~mm}$ & 40.92 & 44.44 & 42.96 \\
\hline \multirow{4}{*}{ COD $_{\text {s }}$ Removal [\%] } & Control & 41.72 & 45.22 & 43.14 \\
\hline & $<0.8 \mathrm{~mm}$ & 56.15 & 69.35 & 64.47 \\
\hline & $1-1.4 \mathrm{~mm}$ & 61.15 & 74.19 & 72.98 \\
\hline & $2-2.36 \mathrm{~mm}$ & 49.72 & 68.54 & 59.47 \\
\hline \multirow{4}{*}{$\begin{array}{c}\text { Methane yield relative to } \\
\text { control [\%] }\end{array}$} & Control & - & - & - \\
\hline & $<0.8 \mathrm{~mm}$ & 59.16 & 46.52 & 49.00 \\
\hline & $1-1.4 \mathrm{~mm}$ & 95.78 & 85.10 & 88.58 \\
\hline & $2-2.36 \mathrm{~mm}$ & 27.82 & 29.64 & 34.00 \\
\hline
\end{tabular}


Table 4. Stimulant metal concentration values $\left(\mathrm{mg} \cdot \mathrm{L}^{-1}\right)$ in anaerobic processes.

\begin{tabular}{|c|c|c|c|c|c|c|c|}
\hline Element & $\begin{array}{c}\text { Weiland } \\
(2006)\end{array}$ & $\begin{array}{c}\text { Kloss } \\
(1986)\end{array}$ & $\begin{array}{c}\text { Seyfried } \\
\text { et al. } \\
(1990)\end{array}$ & $\begin{array}{c}\text { Mudrack } \\
\text { \& Kunst } \\
(2003)\end{array}$ & $\begin{array}{c}\text { Sahm } \\
(1981)\end{array}$ & $\begin{array}{c}\text { Pobeheim } \\
\text { et al. } \\
(2010)\end{array}$ & $\begin{array}{c}\text { Huiliñir } \\
\text { et al. } \\
(2015)\end{array}$ \\
\hline B & - & - & - & - & $0.001-11$ & - & 0.01 \\
\hline $\mathrm{Co}$ & $0.003-$ & $0.5-20$ & $0.003-$ & $0.003-$ & 0.06 & $0.024-10$ & - \\
& 0.06 & & 0.06 & 0.06 & & & \\
\hline $\mathrm{Cr}$ & - & - & - & - & $0.005-52$ & - & - \\
\hline $\mathrm{Cu}$ & - & - & - & - & $0.06-64$ & - & 0.002 \\
\hline $\mathrm{Fe}$ & $1-10$ & $10-200$ & $1-10$ & $1-10$ & - & - & 1.1 \\
\hline $\mathrm{Mn}$ & - & - & - & - & $0.005-55$ & - & 0.01 \\
\hline $\mathrm{Mo}$ & $0.005-$ & $0.1-0.35$ & $0.005-$ & $0.005-$ & 0.05 & $0.16-50$ & - \\
\hline $\mathrm{Ni}$ & $0.005-$ & $0.5-30$ & $0.005-$ & $0.005-$ & 0.006 & $0.24-0.62$ & - \\
\hline $\mathrm{Se}$ & - & $0.1-0.35$ & 0.008 & & 0.008 & - & - \\
\hline
\end{tabular}


Table 5. Comparative results of metal concentrations in digested sludge and class A and B sludge according to the Chilean regulations.

\begin{tabular}{|c|c|c|c|c|c|c|c|}
\hline \multirow{2}{*}{ Sludge source } & \multicolumn{7}{|c|}{ Metal $\left(\mathrm{mg} \cdot \mathrm{kg}^{-1}\right)$} \\
\cline { 2 - 8 } & As & Cd & Cu & Ni & Pb & Se & Zn \\
\hline$<0.8[\mathrm{~mm}]$ & 2.7 & 1.3 & 155.7 & 9.2 & 13.7 & $<\mathrm{DL}$ & 470.7 \\
\hline $1-1.4[\mathrm{~mm}]$ & 2.3 & 1.3 & 154.5 & 8.8 & 13.8 & $<\mathrm{DL}$ & 457.2 \\
\hline $2-2.36[\mathrm{~mm}]$ & 2.4 & 1.3 & 153.9 & 9.3 & 13.6 & $<\mathrm{DL}$ & 451.2 \\
\hline Class A & 20 & 8 & 1000 & 80 & 300 & 50 & 2000 \\
\hline Class B & 40 & 40 & 1200 & 420 & 400 & 100 & 2800 \\
\hline
\end{tabular}




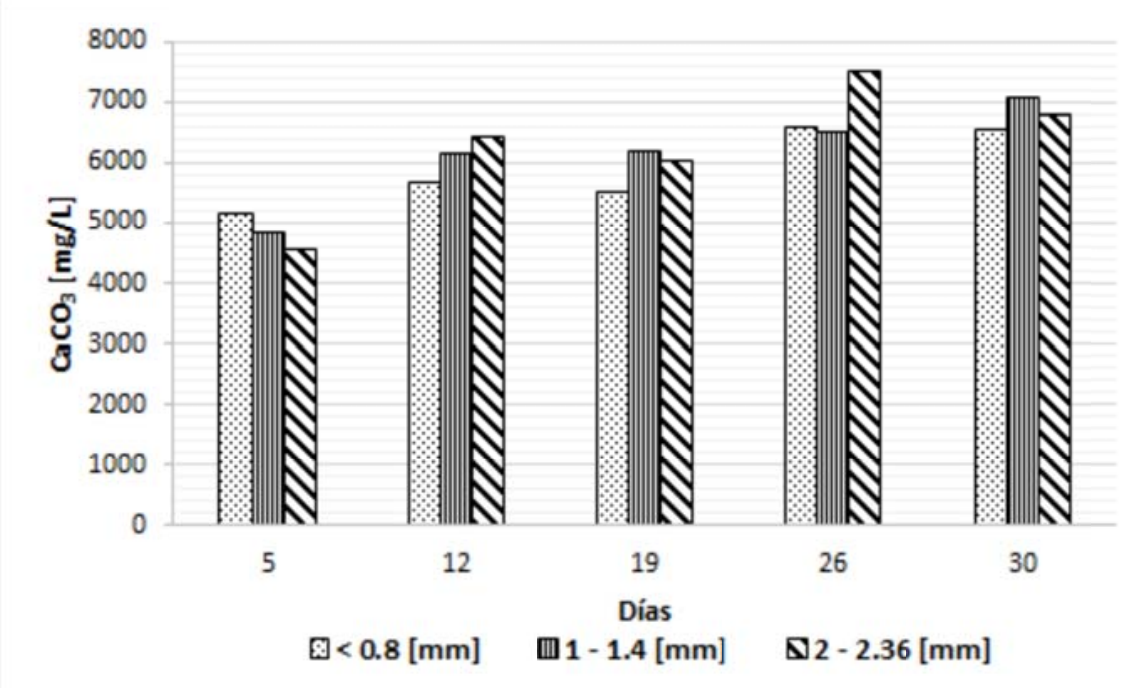

Figure 1. Initial and final alkalinity in anaerobic digesters. 


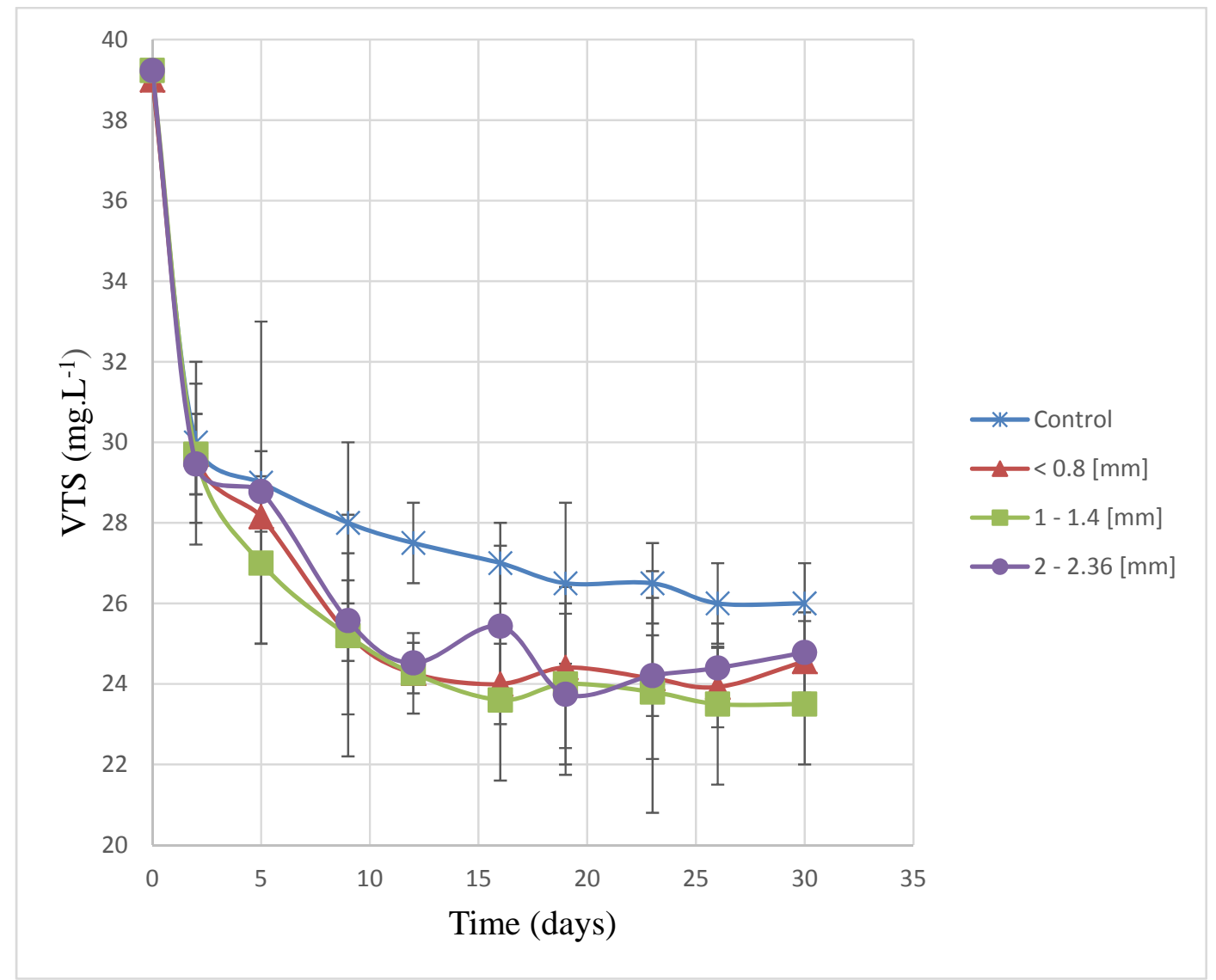

Figure 2. VTS evolution with time in the experimental Series II: AII-1. 


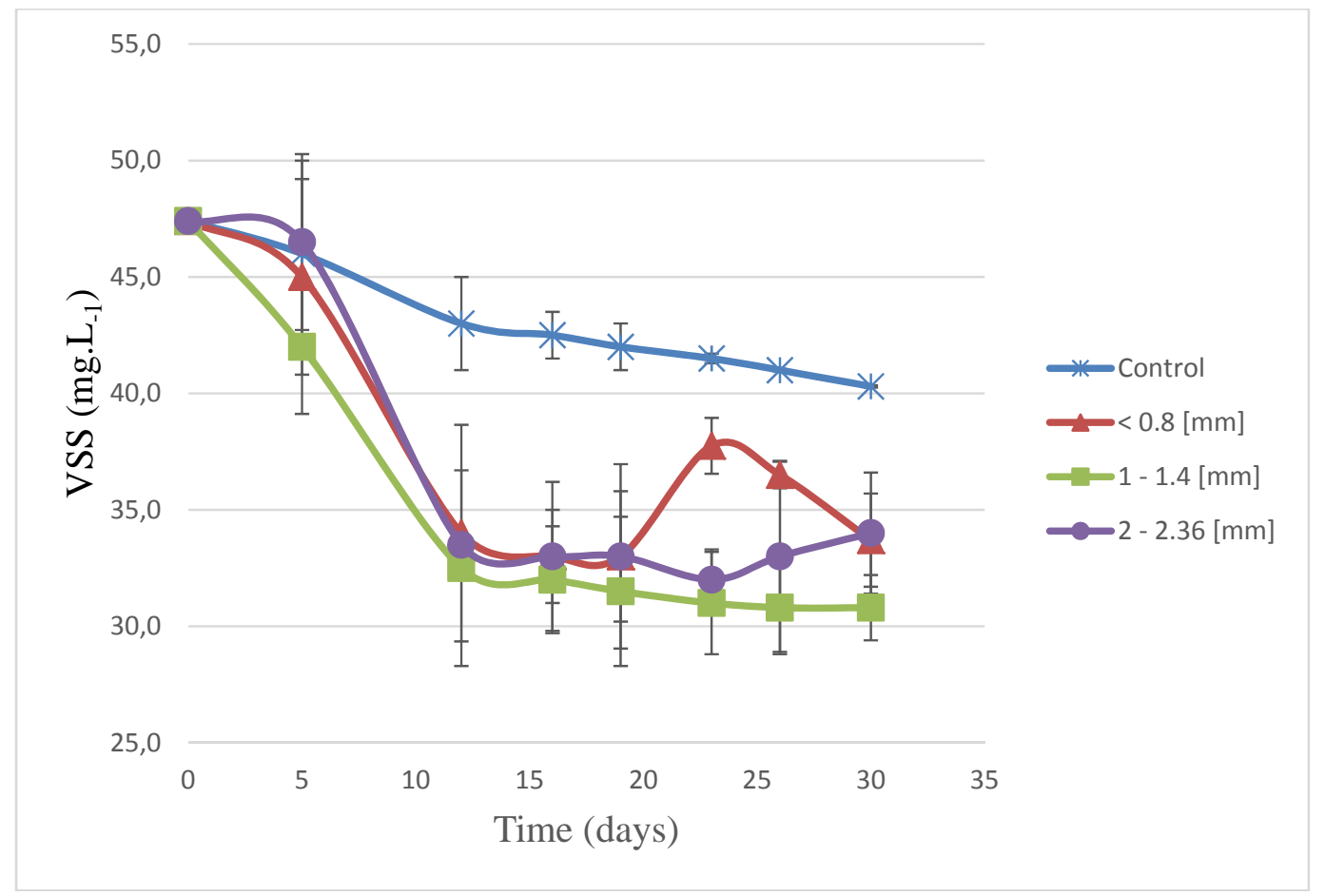

Figure 3. VSS evolution with time in experimental Series II: AII-1. 


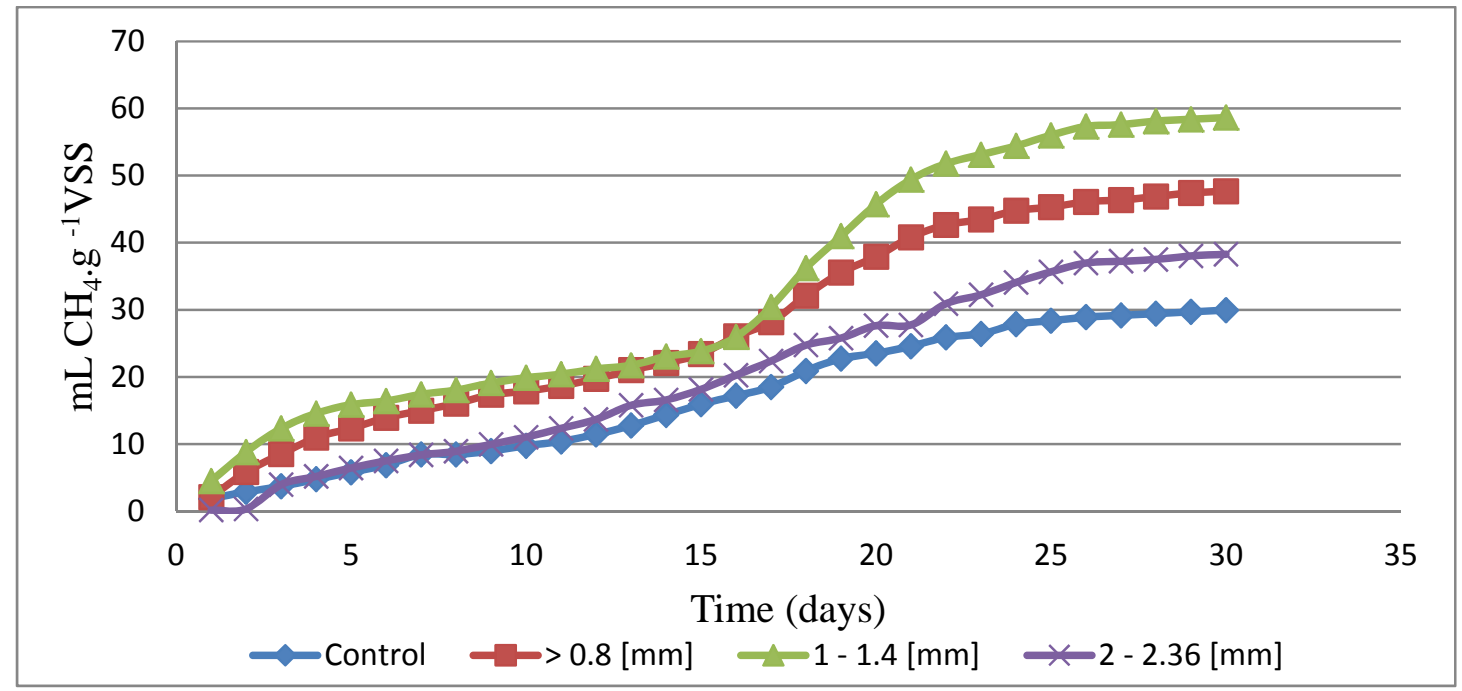

Figure 4. Cumulative methane production in the experimental Series II: AII-1 


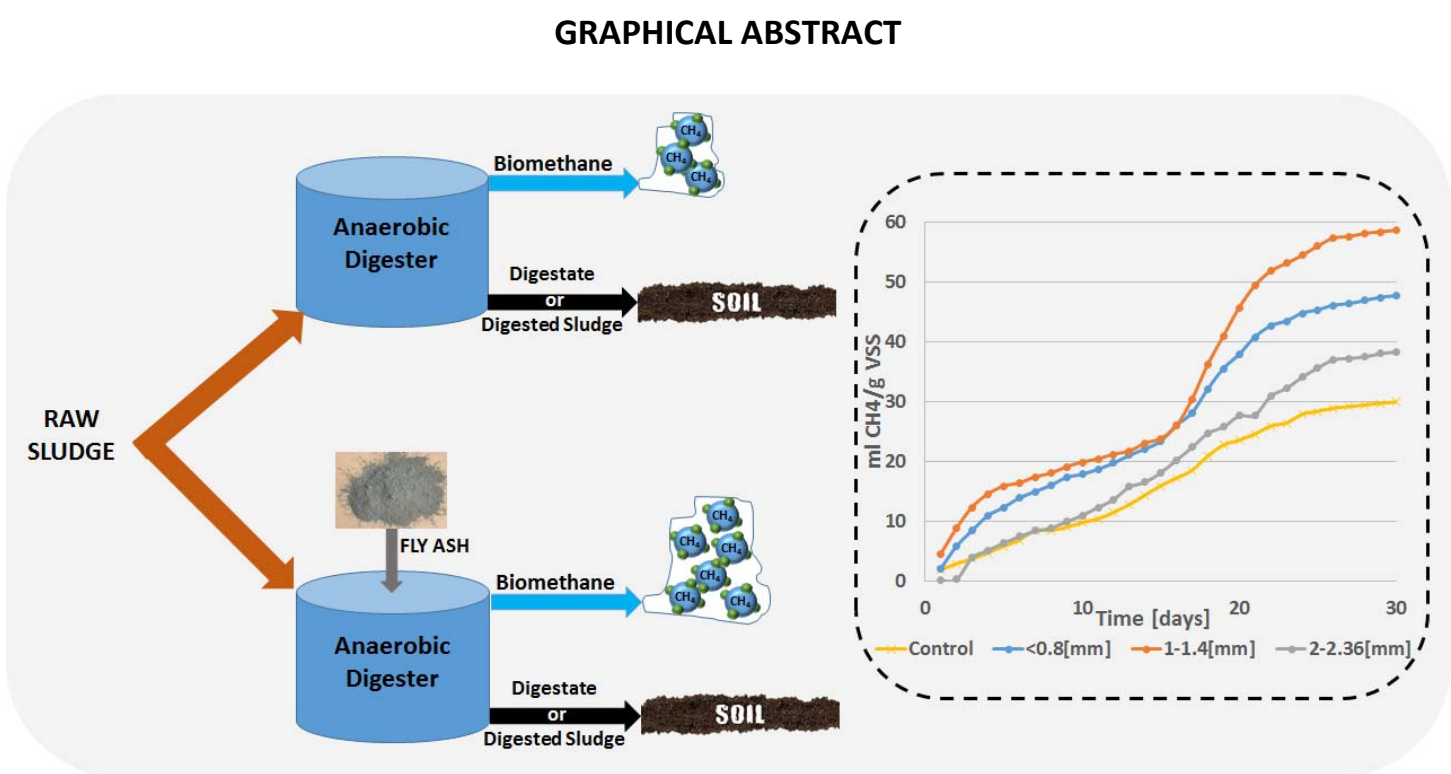

